\title{
AKTIVITAS ANTIOKSIDAN DAUN BAWANG MEKAH (Eleutherine americana Merr.) DENGAN METODE DPPH (2,2-difenil-1-pikrilhidrazil).
}

\author{
Isnindar \\ Bagian Biologi Farmasi Fakultas Kedokteran Universitas Tanjungpura Pontianak \\ Email : isnindar@yahoo.com.
}

\begin{abstract}
Antioxidant is a substance which in small concentrations can significantly inhibit or prevent the oxidation of the substrate. Antioxidant has an important part in health. One of plants that have antioxidant activity is bawang mekah (Eleutherine americana Merr.). This research aims to determine the antioxidant activity of bawang mekah leaves. Antioxidant activity assays performed using DPPH (2,2-diphenyl-1picrylhydrazyl) method, begins with the extraction using ethanol $70 \%$ by maseration. Ethanol fraction performed phytochemical screening with tube test method and preliminary test with DPPH method by silica gel $60 F_{254}$ Thin Layer Chromatography (TLC) eluted by chloroform p.a mobile phase. The antioxidant activity of fraction measured using UV-Vis Spectrophotometer with 10, 20, 30, $40 \mu \mathrm{g} / \mathrm{mL}$ variation concentration and vitamin $C$ with 2; 2,5; 3; 3,5 $\mu \mathrm{g} / \mathrm{mL}$ as a positive control. The results of phytochemical screening showed the fraction contained flavonoids, phenols and saponins. The result of preliminary test gained 1 spot with 12,50 hRf visualized with $366 \mathrm{~nm}$ UV light. The fraction spot showed positive result of antioxidant test was signed by changed color to yellow with purple background after sprayed with DPPH 0,2\%. The results of UV-Vis Spectrophotometer measurements showed the ethanol fraction had antioxidant activity with $I_{50} 45,33694 \mu \mathrm{g} / \mathrm{mL}$ and vitamin $C$ had $I C_{50} 0,62147 \mu \mathrm{g} / \mathrm{mL}$.
\end{abstract}

Key Words: Bawang Mekah Leaves, Maseration, Ethanol Fraction, DPPH

\section{PENDAHULUAN}

Antioksidan merupakan suatu substansi yang pada konsentrasi kecil secara signifikan mampu menghambat atau mencegah oksidasi pada substrat. Ciri utama senyawa antioksidan adalah kemampuannya dalam meredam radikal bebas (Prakash, 2001).

Tanaman bawang mekah termasuk dalam famili Iridaceae.
Masyarakat di berbagai daerah di Kalimantan Barat umumnya menggunakan bagian umbi bawang mekah dalam pengobatan tumor secara tradisional. Umbi bawang mekah dibuat dalam bentuk rebusan dan diminum, sedangkan bagian daunnya seringkali tidak dimanfaatkan. Bawang mekah memiliki kandungan utama berupa polifenol, tanin, alkaloid, saponin, fenolik, dan flavonoid 
(Mangan, 2009; Galingging, 2009; Nur, 2011).

Penelitian terkait terhadap bulbus bawang mekah dilaporkan mempunyai aktivitas sebagai antibakteri (Dwiyana, 2012; Ifesan et al., 2010) dan sebagai antioksidan dengan $\mathrm{IC}_{50}$ sebesar $25,3339 \mu \mathrm{g} / \mathrm{mL}$ (Kuntorini dan Astuti, 2010). Hasil penelitian Pratiwi (2012) menunjukkan bahwa ekstrak etanol $70 \%$ daun bawang mekah menggunakan metode DPPH memiliki aktivitas antioksidan ${ } C_{50}$ sebesar $31,97437 \mu \mathrm{g} / \mathrm{mL}$.

Berdasarkan uraian tersebut untuk melengkapi informasi yang ada, maka dilakukanlah penelitian mengenai uji aktivitas antioksidan fraksi etanol daun bawang mekah (Eleutherine americana Merr.) dengan metode DPPH (2,2-difenil-1pikrilhidrazil).

\section{METODE PENELITIAN}

\section{Alat dan Bahan}

Alat yang digunakan dalam penelitian ini adalah pisau, lemari pendingin, blender simplisia (IlinQi tipe FZ-10), waterbath (Memmert tipe WNB 22), timbangan analitik (BEL tipe M254Al), alat maserasi (Pyrex lwaki), spektrofotometer UV-Vis (Shimadzu tipe MR 2500), sendok stainless, oven (Memmert tipe UP400), krusibel porselen, desikator, alat-alat gelas
(Pyrex Iwakı), Vortex (Barnstead tipe M37610) dan mikropipet (Rainin tipe E1019705K).

Bahan yang digunakan dalam penelitian ini adalah daun bawang mekah, DPPH p.a (Merck), kloroform p.a (Merck, 1024452500), n-heksan p.a (Merck, 1043672500), vitamin C (Kimia Farma, 1111070260), metanol p.a (Merck, 1060092500), etanol 70\%, serbuk magnesium (Merck, 1087801000), larutan $\mathrm{HCl} 2 \mathrm{~N}$, larutan $\mathrm{FeCl}_{3} 1 \%$, pereaksi LiebermanBurchad, pereaksi Dragendorff, pereaksi Meyer, aquades, aluminium foil, kertas saring, dan lempeng Kromatografi Lapis Tipis (silika gel 60 $\mathrm{GF}_{254)}$ (Merck, 1055540001).

\section{Prosedur Kerja}

\section{Determinasi Tanaman}

Tanaman bawang mekah yang diteliti dideterminasi di Laboratorium Biologi Fakultas Matematika dan IImu Pengetahuan Alam Universitas Tanjungpura Pontianak, dengan menyerahkan sampel utuh tanaman bawang mekah.

\section{Pengambilan dan Pengolahan Sampel}

Tanaman bawang mekah yang digunakan diambil di Jalan Patok 35 desa Limbung, Kecamatan Sungai Raya, Kabupaten Kubu Raya, Provinsi Kalimantan Barat. Daun bawang 
mekah diambil pada saat umur 6 bulan.

Daun bawang mekah yang telah dikumpulkan, dan dibersihkan. Kemudian daun dirajang dan dikeringkan dengan cara dioven. Kemudian daun kering disimpan dalam wadah kering.

\section{Pembuatan Ekstrak}

$\begin{array}{rrr}\text { Sebanyak } & 251,25 & \text { gram } \\ \text { simplisia daun bawang mekah }\end{array}$ dimasukkan dalam alat maserasi yang telah di rangkai. Dimaserasi menggunakan pelarut etanol $70 \%$ selama 3 hari, dengan melakukan pengadukan secara berkala dan penggantian pelarut setiap hari. Filtrat dipekatkan menggunakan waterbath hingga diperoleh ekstrak etanol.

\section{Penetapan Susut Pengeringan}

sebanyak 1 gram ekstrak ditimbang seksama dan dimasukkan ke dalam krus porselen bertutup yang sebelumnya telah dipanaskan pada suhu $105^{\circ} \mathrm{C}$ selama 30 menit dan telah ditara. Dimasukkan kedalam oven, dibuka tutup krus, panaskan pada suhu $105^{\circ} \mathrm{C}$, timbang dan ulangi pemanasan hingga diperoleh bobot konstan.

\section{Skrining Fitokimia}

\section{Pemeriksaan Alkaloid}

Larutan ekstrak sebanyak $3 \mathrm{~mL}$ ditambah $1 \mathrm{~mL} \mathrm{HCl} 2 \mathrm{~N}$ dan $6 \mathrm{~mL}$ aquades, dipanaskan di atas penangas air selama 2 menit, didinginkan dan disaring. Sebanyak 3 tetes filtrat dipindahkan pada kaca arloji, kemudian diperiksa adanya senyawa alkaloid dengan menambahkan pereaksi Meyer dan Dragendroff masing-masing sebanyak 2 tetes. Adanya alkaloid ditandai dengan terbentuknya endapan putih dengan pereaksi Meyer dan endapan merah dengan pereaksi Dragendorff (Departemen Kesehatan Republik Indonesia, 1989).

\section{Pemeriksaan Flavonoid}

Larutan ekstrak sebanyak $2 \mathrm{~mL}$ ditambah dengan sedikit serbuk seng atau magnesium dan $2 \mathrm{~mL} \mathrm{HCl} 2 \mathrm{~N}$. Senyawa flavonoid akan menimbulkan warna jingga sampai merah (Departemen Kesehatan Republik Indonesia, 1989).

\section{Pemeriksaan Saponin}

Larutan ekstrak sebanyak $1 \mathrm{~mL}$ ditambahkan $10 \mathrm{~mL}$ aquades dan dikocok kuat selama 10 menit. Hasil dinyatakan positif apabila buih yang terbentuk stabil selama tidak kurang dari 10 menit, setinggi $1 \mathrm{~cm}$ sampai 10 $\mathrm{cm}$. Pada penambahan 1 tetes $\mathrm{HCl} 2$ $\mathrm{N}$, buih tidak hilang (Departemen Kesehatan Republik Indonesia, 1989). 
Pemeriksaan Terpenoid dan steroid

Sebanyak $1 \mathrm{~mL}$ larutan ekstrak kental diuapkan sampai kering, kemudian ditambah dengan pereaksi Lieberman-Burchad. Jika warna berubah menjadi biru atau ungu, menandakan adanya senyawa steroid. Jika warna berubah menjadi merah, menunjukkan adanya senyawa terpenoid (Harborne, 1987).

\section{Pemeriksaan Fenol}

Sebanyak $2 \mathrm{~mL}$ ekstrak ditambahkan dengan $10 \mathrm{~mL}$ aquades lalu dididihkan selama 10 menit dalam tangas air mendidih. Larutan kemudian disaring dan filtratnya ditambahkan dengan 3 tetes $\mathrm{FeCl}_{3}$ 1\%. Terjadinya warna hijau-biru menunjukkan adanya fenolat (Harborne, 1987).

\section{Uji Pendahuluan Aktivitas}

\section{Antioksidan}

Uji pendahuluan aktivitas antioksidan merujuk pada metode Isnindar et al. (2011) dengan cara kromatogram hasil KLT disemprot larutan $0,2 \%$ DPPH dalam metanol p.a. Ekstrak etanol $70 \%$ ditotolkan pada fase diam silika gel $60 \mathrm{~F}_{254}$ dan dielusi dengan fase gerak kloroform p.a. Jarak pengembangan adalah 8 $\mathrm{cm}$. Bercak yang terbentuk diamati dengan sinar tampak, lampu UV 366 $\mathrm{nm}$, disemprot dengan pereaksi DPPH
$0,2 \%$. Dihitung nilai $\mathrm{Rf}$ dengan rumus (Gandjar dan Rohman, 2007):

$$
\begin{aligned}
& \text { Jarak yang ditempuh } \\
& \mathrm{Rf}=\frac{\text { sampel }}{\text { Jarak yang ditempuh fase }} \\
& \text { gerak }
\end{aligned}
$$

Fraksinasi

Ekstrak daun bawang mekah dilarutkan dengan n-heksan, kemudian dimasukkan dalam tabung reaksi, divortek hingga terjadi pemisahan. Bagian yang tidak terlarut dalam nheksan (fase bawah) diambil dan dimasukkan ke dalam tabung reaksi lagi, kemudian ditambahkan kloroform, divortek hingga terjadi pemisahan. Bagian yang tidak terlarut dalam kloroform (fase atas) diambil dan dimasukkan ke dalam tabung reaksi, kemudian ditambahkan dengan etanol dan divortek hingga terjadi pemisahan. Ambil bagian yang terlarut dalam etanol.

\section{Pembuatan Larutan DPPH 0,1 mM}

Kristal DPPH sebanyak 0,985 mg dimasukkan kedalam labu ukur 25 $\mathrm{mL}$ dan ditambahkan pelarut metanol p.a sampai garis tanda.

\section{Skrining Panjang Gelombang Maksimal Larutan DPPH 0,1 mM \\ Penentuan panjang gelombang maksimum ( $\left.\lambda_{\text {maks }}\right) \quad$ DPPH $0,1 \mathrm{mM}$ menggunakan spektrofotometri UV-Vis dan dibaca serapannya pada panjang}


gelombang 400-700nm (Musfiroh dan Syarief, 2012).

\section{Pengukuran Aktivitas Antioksidan Menggunakan \\ Spektrofotometer UV-Vis}

Aktivitas antioksidan fraksi etanol daun bawang mekah ditentukan dengan metode DPPH yang digunakan oleh Mosquera et al. (2009). Variasi konsentrasi sampel uji adalah 10, 20, 30, dan $40 \mu \mathrm{g} / \mathrm{mL}$ dan vitamin C sebagai kontrol positif adalah $2 ; 2,5 ; 3 ; 3,5 \mu \mathrm{g} / \mathrm{mL}$. Masingmasing variasi konsentrasi dipipet 1 $\mathrm{mL}$ kemudian ditambahkan ke dalam 2 $\mathrm{mL}$ DPPH dan dibiarkan selama 30 menit pada suhu kamar di tempat gelap. Lalu diukur absorbansinya pada panjang gelombang maksimum ( $\left.\lambda_{\text {maks }}\right)$ DPPH 0,1 mM.

Data hasil pengukuran absorbansi dianalisa persentase aktivitas antioksidannya dengan menggunakan rumus berikut:

$\%$ Peredaman $=\frac{\left(A_{\mathrm{DPPH}}-\mathrm{A}_{\text {sampel }}\right)}{A_{\mathrm{DPPH}}} \times 100 \%$

Selanjutnya dilakukan perhitungan $\mathrm{IC}_{50}$ melalui persamaan regresi linier yang menyatakan hubungan antara konsentrasi sampel uji (X) dengan persen aktivitas penangkap radikal rata-rata $(\mathrm{Y})$.

\section{HASIL PENELITIAN}

Tabel 1. Hasil Skrining Fitokimia Ekstrak Etanol 70\% dan Fraksi Etanol.

\begin{tabular}{|c|c|c|c|c|c|}
\hline $\begin{array}{l}\text { Metabolit } \\
\text { Sekunder }\end{array}$ & Pereaksi & $\begin{array}{c}\text { Hasil pengamatan } \\
\text { Ekstrak }\end{array}$ & Ket & $\begin{array}{c}\text { Hasil Pengamatan } \\
\text { Fraksi }\end{array}$ & Ket \\
\hline Alkaloid & Mayer dan Dragendorff & $\begin{array}{l}\text { Tidak terjadi } \\
\text { Perubahan }\end{array}$ & - & $\begin{array}{l}\text { Tidak terjadi } \\
\text { Perubahan }\end{array}$ & - \\
\hline $\begin{array}{l}\text { Flavonoid } \\
\text { Saponin }\end{array}$ & $\begin{array}{l}\mathrm{HCl} 2 \mathrm{~N}+\text { Serbuk Mg } \\
\text { Aquades + HCL } 2 \mathrm{~N}\end{array}$ & $\begin{array}{c}\text { Jingga kemerahan } \\
\text { Berbusa }\end{array}$ & $\begin{array}{l}+ \\
+\end{array}$ & $\begin{array}{l}\text { Jingga } \\
\text { Berbusa }\end{array}$ & $\begin{array}{l}+ \\
+\end{array}$ \\
\hline $\begin{array}{l}\text { Triterpenoid } \\
\text { /Steroid }\end{array}$ & Lieberman-Burchad & $\begin{array}{l}\text { Tidak terjadi } \\
\text { perubahan }\end{array}$ & - & $\begin{array}{l}\text { Tidak terjadi } \\
\text { perubahan }\end{array}$ & - \\
\hline Fenol & $\mathrm{FeCl}_{3}$ & Biru kehitaman & + & Biru kehitaman & + \\
\hline
\end{tabular}

Keterangan: $(+)=$ ada, $(-)=$ tidak ada

Tabel 2. Hasil Pengukuran Aktivitas Antioksidan Fraksi Etanol dengan DPPH 0,1mM

\begin{tabular}{ccccc}
\hline $\begin{array}{c}\text { Konsentrasi } \\
(\boldsymbol{\mu g} / \mathbf{m L})\end{array}$ & Absorbansi & $\begin{array}{c}\text { \% Aktivitas } \\
\text { Antioksidan }\end{array}$ & $\begin{array}{c}\mathbf{I C}_{50} \\
(\boldsymbol{\mu g} / \mathbf{m L})\end{array}$ & $\begin{array}{c}\text { Potensi } \\
\text { Antioksidan }\end{array}$ \\
\hline Blanko & 0,5150 & - & & \\
10 & 0,35950 & 30,1941 & & \\
20 & 0,31872 & 38,1126 & 45,33694 & Sangat kuat \\
30 & 0,28944 & 43,7980 & & \\
40 & 0,28005 & 45,6213 & & \\
\hline
\end{tabular}


Tabel 3. Hasil Pengukuran Aktivitas Antioksidan Vitamin C dengan DPPH 0,1mM

\begin{tabular}{ccccc}
\hline $\begin{array}{c}\text { Konsentrasi } \\
(\mu \mathbf{g} / \mathbf{m L})\end{array}$ & Absorbansi & $\begin{array}{c}\text { \% Aktivitas } \\
\text { Antioksidan }\end{array}$ & $\begin{array}{c}\mathbf{I C}_{50} \\
(\boldsymbol{\mu g} / \mathbf{m L})\end{array}$ & $\begin{array}{c}\text { Potensi } \\
\text { Antioksidan }\end{array}$ \\
\hline Blanko & 1,3260 & - & & \\
2 & 0,56944 & 57,05580 & & \\
2,5 & 0,52106 & 60,70437 & 0,62147 & Sangat kuat \\
3 & 0,48773 & 63,21795 & & \\
3,5 & 0,46050 & 65,27149 & & \\
\hline
\end{tabular}

\section{PEMBAHASAN}

\section{Ekstraksi Daun Bawang Mekah}

Metode ekstraksi secara maserasi dipilih untuk penyarian karena menghasilkan ekstrak yang banyak dan baik untuk bahan aktif yang tidak tahan oleh adanya pemanasan. Pelarut etanol $70 \%$ dipilih sebagai penyari dikarenakan pelarut ini sangat efektif dalam menghasilkan jumlah bahan aktif yang optimal. Menurut Syamsuni (2006), selain sebagai penyari, etanol dapat digunakan sebagai pengawet ekstrak karena menyebabkan enzim-enzim tidak bekerja sehingga jamur dan bakteri tidak tumbuh. Ekstrak yang diperoleh sebanyak 52,1 gram, berwarna coklat kehijauan. Redemen ekstrak terhadap simplisia kering adalah 20,7363\%.

\section{Penetapan Susut Pengeringan}

Hasil susut pengeringan diperoleh kadar pelarut yang tersisa sebesar 5,72 \%. Menurut Voigt (1995), ekstrak tersebut tergolong ekstrak kental (Extractum spissum) karena kadar pelarut yang tersisa diantara 5$30 \%$.

\section{Skrining Fitokimia Ekstrak Etanol} $70 \%$ dan Fraksi Etanol

Hasil skrining fitokimia ekstrak etanol $70 \%$ dan fraksi etanol dapat dilihat pada tabel 1. Fraksi etanol daun bawang mekah mengandung metabolit sekunder yang sama dengan ekstrak yaitu berupa flavonoid, saponin, dan fenolik. Senyawa yang memberikan hasil negatif kemungkinan tidak ikut terekstraksi oleh pelarut.

\section{Uji Pendahuluan Aktivitas}

Antioksidan Ekstrak Etanol 70\% dan Fraksi Etanol secara KLT

Uji pendahuluan bertujuan untuk mengetahui ada atau tidaknya senyawa aktif di dalam ekstrak yang memiliki aktivitas antioksidan dalam meredam radikal bebas (DPPH). Fase gerak yang digunakan ialah kloroform p.a, yang dipilih berdasarkan hasil optimasi. Hasil KLT pada ekstrak diperoleh 4 bercak dengan hRf 3,75; 12,50; 50,00 dan 61,25 sedangkan pada fraksi diperoleh 1 bercak pada 
hRf 12,50 . Setelah disemprot dengan DPPH $0,2 \%$, seluruh bercak pada ekstrak maupun fraksi memberikan hasil positif yang ditandai dengan terbentuknya warna kuning pucat dengan latar ungu.

Deteksi menggunakan sinar UV dengan panjang gelombang $366 \mathrm{~nm}$ juga dilakukan untuk mengetahui bercak yang dapat berfluoresensi (berpendar) sehingga dapat terlihat secara visual. Peristiwa ini disebabkan oleh adanya interaksi antara sinar UV dengan gugus kromofor yang terikat oleh auksokrom pada bercak tersebut. Fluoresensi cahaya yang tampak merupakan hasil emisi cahaya yang dipancarkan ketika elektron tereksitasi dari tingkat dasar ke tingkat energi yang lebih tinggi dan kembali ketingkat semula sambil melepaskan energi.

\section{Uji Aktivitas Antioksidan Secara} Spektrofotometer UV-Vis

Pemilihan metode DPPH untuk penentuan aktivitas antioksidan didasarkan pada keunggulannya, yaitu mudah, cepat, sederhana, reprodusibel, baik untuk sampel dengan polaritas tertentu, sensitif dan hanya membutuhkan sedikit sampel (Kurniawan, 2011).

Hasil skrining panjang gelombang maksimum larutan DPPH $0,1 \mathrm{mM}$ pada fraksi etanol daun bawang mekah dan vitamin C sebagai kontrol positif adalah sama, yaitu $515,4 \mathrm{~nm}$.

Hasil persamaan regresi linier fraksi etanol adalah $y=0,51967 x+$ 26,43975 dengan nilai $r=0,9668$. Nilai $\mathrm{IC}_{50}$ fraksi etanol adalah $45,33694 \mu \mathrm{g} / \mathrm{mL}$. Menurut Molyneux (2004), fraksi etanol ini memiliki aktivitas antioksidan yang sangat kuat karena nilai $\mathrm{IC}_{50}$ nya kurang dari 50 $\mu \mathrm{g} / \mathrm{mL}$. Hasil pengukuran fraksi dapat dilihat pada tabel 2 .

Hasil pengukuran vitamin C pada tabel 4, diperoleh persamaan regresi linier $y=5,43213 x+46,62404$ dengan nilai koefisien korelasi 0,99119. Vitamin C sebagai kontrol positif mempunyai nilai $\mathrm{IC}_{50}$ sebesar $0,62147 \mu \mathrm{g} / \mathrm{mL}$. Nilai tersebut menunjukkan bahwa vitamin $\mathrm{C}$ tergolong antioksidan yang sangat kuat karena memiliki nilai $I_{50}$ kurang dari $50 \mu \mathrm{g} / \mathrm{mL}$. Jika ditinjau dari strukturnya, kuatnya aktivitas antioksidan vitamin $\mathrm{C}$ dipengaruhi oleh banyaknya gugus - $\mathrm{OH}$ yang terikat pada struktur inti vitamin $\mathrm{C}$.

Nilai $\mathrm{IC}_{50}$ fraksi etanol daun bawang mekah menunjukkan bahwa fraksi etanol tersebut memiliki aktivitas antioksidan yang sangat kuat begitu juga dengan vitamin C. Tetapi aktivitas antioksidan fraksi etanol daun bawang 
mekah lebih rendah jika dibandingkan dengan vitamin C sebagai kontrol positif karena fraksi etanol daun bawang mekah masih terdiri dari beberapa campuran senyawa, sedangkan vitamin $\mathrm{C}$ adalah senyawa murni.

\section{KESIMPULAN}

Fraksi Etanol daun bawang mekah secara maserasi positif memiliki aktivitas antioksidan menggunakan DPPH 0,2\%. Aktivitas antioksidan fraksi etanol daun bawang mekah tergolong sangat kuat dengan nilai IC $_{50} \quad 45,33694 \mu \mathrm{g} / \mathrm{mL}$ (Nilai IC $_{50}$ Vitamin C sebagai kontrol positif sebesar 0,62147 $\mu \mathrm{g} / \mathrm{mL}$ ).

\section{DAFTAR PUSTAKA}

Departemen Kesehatan Republik Indonesia, 1989, Materia Medika Indonesia. Jilid V, Departemen Kesehatan Republik Indonesia, Jakarta, Hal 179, 333-337, 549-553.

Dwiyana, U. D., 2012, Penentuan Aktivitas Antibakteri Umbi Bawang Mekah (Eleutherine americana (L.) Merr ) terhadap Staphylococcus aureus Dan Escherichia coli Beserta Profil Kromatografi Lapis Tipis, Skripsi, Program Studi Farmasi Fakultas Kedokteran Universitas Tanjungpura.

Galingging, R. Y. 2009. Bawang Dayak (Eleutherine palmifolia) sebagai Tanaman Obat Multifungsi. Warta Penelitian dan Pengembangan Badan
Penelitian dan Pengembangan Pertanian. 15 (3) 10-16.

Gandjar, I. G. dan Rohman, A., 2007, Kimia Farmasi Analisis, Penebar Swadaya, Yogyakarta, Hal 234-235, 261-262.

Harborne, J. B., 1987, Metode Fitokimia: Penuntun Cara Modern Menganalisis Tumbuhan, Penerbit ITB, Bandung, Hal 70, 147-148, 243235.

Ifesan, B. O. T., Ibrahim, D., and Voravuthikunchai, S. P., 2010, Antimicrobial Activity of Crude Ethanolic Extract from Eleutherine americana, J. Food-Agri, 8 (3) 1233-1236.

Isnindar, Setyowati, E. P., dan Wahyuono, S., 2011, Aktivitas Antioksidan Daun Kesemek (Diospyros kaki L.F) dengan Metode DPPH (2,2-Difenil-1 Pikrilhidrazil), Majalah Obat Tradisional, 16 (2) 63-67.

Jawi, I. M., Suprapta, N. D., dan Sutirtayasa, I. W. P., 2007, Efek Antioksidan Ekstrak Umbi Ubijalar Ungu ( Ipomoiea batatas L) terhadap Hati Setelah Aktivitas Fisik Maksimal dengan Melihat Kadar AST dan ALT Darah pada Mencit, Dexa Media, 20 (3) 65-71.

Kuntorini, E. M. dan Astuti, M. D., 2010, Penentuan Aktivitas Antioksidan Ekstrak Etanol Bulbus Bawang Dayak (Eleutherine americana Merr.), Sains dan Terapan Kimia, 4 (1) 15-22.

Kurniawan, A., 2011, Aktivitas Antioksidan dan Potensi Hayati 
dari Kombinasi Ekstrak Empat Jenis Tanaman Obat Indonesia, Skripsi, Departemen Biokimia FMIPA Institut Pertanian Bogor, Hal 6-7.

Mangan, Y., 2009, Solusi Mencegah dan Mengatasi Kanker, Agromedia Pustaka, Jakarta, Hal 64.

Molyneux, P., 2004, The Use of The Stable Free Radical Diphenylpicrylhydrazyl (DPPH) for Estimating Antioxidant Activity, Songklanakarin. J. Sci. Technol, 26 (2) 211-219.

Mosquera, O., Correa, Y. M., and Nino, J., 2009, Antioxidant Activity of Plants Extract from Colombian Flora Braz, J. Pharm, 19 (2A) 382-387.

Musfiroh, E dan Syarief, S. H., 2012, Uji Aktivitas Peredaman Radikal Bebas Nanopartikel Emas Dengan Berbagai Konsentrasi Sebagai Material Antiaging Dalam Kosmetik, UNESA. J. Chem, 1 (2) 18-25.

Nur, A. M., 2011, Kapasitas Antioksidan Bawang Dayak (Eleutherine palmifolia) Dalam Bentuk Segar, Simplisia dan Keripik, Pada Pelarut Nonpolar, Semipolar dan Polar, Skripsi, Institut Pertanian Bogor.

Prakash, A., 2001, Antioxidant Activity, Analytical Progress, 19 (2) 1-4.

Pratiwi, D., 2012, Uji Aktivitas Antioksidan Daun Bawang Mekah (Eleutherine americana Merr.) Dengan Metode DPPH (2,2-difenil-1-pikrilhidrazil), Skripsi, Program Studi Farmasi
Fakultas

Kedokteran

Universitas Tanjungpura.

Syamsuni, H. A., 2006, Ilmu Resep, Buku Kedokteran EGC, Jakarta, Hal 243, 246-249, 263.

Voigt, R., 1995, Buku Pelajaran Teknologi Farmasi, UGM Press, Yogyakarta, Hal 561, 567-569, 577.

Wulansari, D. dan Chairul, 2011, Penapisan Aktivitas Antioksidan dan Beberapa Tumbuhan Obat Indonesia Menggunakan Radikal 2,2-Diphenyl-1 Picrylhydrazyl (DPPH), Majalah Obat Tradisional, 16 (1) $22-2$ 